\title{
RANCANG BANGUN SISTEM OTOMATISASI DAN TELEKONTROL PADA PENGKONDISIAN AIR KOLAM PEMBIBITAN IKAN NILA
}

\author{
Limbran Sampebatu ${ }^{1}$, Aries Kamolan ${ }^{2}$ \\ Jurusan Teknik Elektro, Fakultas Teknik, Universitas Atmajaya Makassar \\ e-mail: elsampebatu@gmail.com, arieskamolan@gmail.com
}

\begin{abstract}
ABSTRAK
Ikan nila adalah salah satu jenis ikan yang bernilai ekonomis tinggi sehingga kebutuhan benih maupun ikan yang layak cenderung meningkat setiap tahunnya. Seiring meningkatnya permintaan ikan maka harus diiringi dengan penyedian benih ikan yang berkualitas, di mana hal ini sangat ditentukan oleh kondisi air kolam seperti suhu, kejernihan dan ketinggian air. Penelitian ini membuat rancang bangun suatu sistem yang mengatur kondisi suhu optimal untuk kolam pembibitan ikan yaitu $25^{\circ}-30^{\circ}$ celcius. Apabila suhu air kolam dibawah $25^{\circ}$ celcius maka sistem mengaktifkan heater sampai pada suhu $28^{\circ}$ celcius. Untuk ketinggian air yang baik untuk kolam pembibitan adalah berkisar antara 40-60 centimeter. Penelitian ini mensimulasikan tiga level ketinggian yaitu rendah, normal, dan tinggi. Pada saat air berada pada kondisi level air tinggi maka pompa pengurasan aktif hingga ketinggian air sampai pada level normal yang akan menghentikan pompa. Selanjutnya pada saat level air rendah, maka pompa akan mengisi kolam hingga pada level normal yang akan menghentikan kerja pompa. Untuk kejernihan air, kondisi yang diharapkan adalah air yang jernih dan bersih. Pada saat air keruh maka pompa pengurasan akan aktif sampai batas level rendah kemudian melakukan pengisian kembali sampai batas normal. Hasil simulasi penelitian ini memperlihatkan bahwa rancang bangun prototipe otomatisasi kontrol pengkondisian air, sudah dapat melakukan pengurasan, pengisian, penjernihan dan penghangatan otomatis serta mampu mengirim pesan pada pengguna.
\end{abstract}

Kata Kunci : Ikan Nila, Otomatisasi, Sensor Suhu, Sensor Ketinggian, Sensor Kejernihan Air

\begin{abstract}
The needs of Tilapia is quite high and popular for that the needs of this fish increasingly every year. The needs of tilapia should be support also by the availability of its seeds which determan by the ponds water conditions such as temperature, water clarity and its height. This research designs a prototype of a system to maintain the optimum temperature condition in the range of $25^{\circ}-30^{\circ}$ celcius for tilapia seeds pond. When the system indicate that the water temperature hits $25 \mathrm{oC}$ or below, it activate the heater to heat the water pond until it reach the temperature of $28 \mathrm{oC}$. The fish seeds develop well for the water height between $40-60 \mathrm{~cm}$. When the water is too high so the system will activate the pump to drain the pond to the normal level, otherwise the pump will fill the pond whenever the system indicate the water level in the pond is low. The best water for tilapia seeds is a pond with clear and clean water. The the water pond indicate to be muddy it also activate the pump to drain water to the low level and fill it again to the normal level. This simulation results show that the prototype of automation of water conditioning controller has work properly to drain, to fill, to clarify, to warm the water pond automatically and able to send messages to the user about those condition.
\end{abstract}

Keywords : Tilapia, Automation, Temperature Sensors, Height Sensors, Water Clarity Sensors

\section{PENDAHULUAN}

Ikan nila adalah salah satu jenis ikan yang bernilai ekonomis tinggi, kebutuhan benih dan konsumsi ikan nila dari tahun ke tahun cenderung terus meningkat seiring dengan perluasan usaha budidaya. Menurut Kementerian Kelautan dan Perikanan (2014) produksi ikan nila mengalami peningkatan dari 567.078 ton pada tahun 2011 naik menjadi 1,1 juta ton pada tahun 2013. Namun peningkatan produksi ikan nila masih terhambat oleh beberapa kendala yang sampai saat ini masih belum teratasi. [1]

Salah satu kendala yang masih menghambat peningkatan produksi ikan nila adalah rendahny a kualitas dan kuantitas benih. Hat ini membuat harga benih di pasaran untuk ukuran

\section{Rancang Bangun Sistem Otomatisasi Dan Telekontrol Pada Pengkondisian Air Kolam Pembibitan Ikan Nila}


yang siap ditempatkan di kolam pembesaran menjadi mahal. Menurut Sumantadina dalam [1] jaminan penyediaan benih ikan baik kualitas maupun kuantitas yang memadai merupakan salah satu syarat yang menentukan keberhasilan suatu usaha budidaya ikan. Kualitas dan penanganan induk sangat penting dalam kaitannya untuk menghasilkan benih yang baik.

Pemeliharan benih ikan cukup sensitif karena terdapat beberapa kondisi yang harus dipenuhi, seperti ketinggian air, suhu dan kejernihan. Karena benih ikan yang baru menetas sangat rentan dan sensitif terhadap perubahan kondisi lingkungan. Kondisi yang perlu diperhatiakan itu berupa Ketinggian air yang baik untuk pemebibitan ikan antara 60-75 cm, kualitas air untuk pembibitan ikan nila harus bersih dan jernih tidak keruh dan tidak tercemar bahan-bahan kimia beracun, dan minyak/limbah pabrik. Suhu kolam yang masih bisa ditolerir ikan nila adalah 15-37 C. Suhu optimum untuk petumbuhan ikan adalah 25-30 C. Sementara untuk pemijahan, suhu ideal untuk bisa menghasilkan telur dan larva berkisar 22-37C. Ketika suhu menjadi dingin maka akan membuat ikan tidak aktif dan tidak lahap. Ikan nila sebaiknya hidup di air dengan kadar oksigen terlarut lebih dari 3 PPM. Jika kurang dari 3PPM, bisa menghambat laju pertumbuhan. Normalnya pertumbuhan ikan nila 4 bulan mencapai 300-400 gram. Untuk menambah oksigen yang masuk biasanya dibuat saluran air. Serta derajat keasaman atau PH idealnya untuk pertumbuhan dan perkembangbiakan ikan nila adalah 7. Jika PH terlalu rendah atau asam bisa dinetralisir dengan memberikan kapur, jika PH terlalu tinggi atau basa, perlu diberikan belerang dalam bentuk serbuk. [2]

Berdasarkan kondisi-kondisi di atas maka penelitian ini membuat suatu sistem yang dapat mengontrol kondisi air untuk kolam pembibitan ikan nila dengan judul "Rancang Bangun Sistem Otomatisasi dan Telekontrol Pengkondisian Air Kolam Pembibitan Ikan Nila"untuk membantu para pengusaha pembibitan ikan nila mendapatkan ikan yang sehat, bebas penyakit, bermutu, dan lezat untuk dikonsumsi.

\section{Ikan nila}

Ikan nila (Oreochromis niloticus) merupakan jenis ikan air tawar cukup diminati. Untuk mmelihara ikan nila diperlukan kolam pemeliharaan dengan jenis tanah liat/lempung, tidak berporos. Jenis tanah tersebut dapat menahan massa air yang besar dan tidak bocor sehingga dapat dibuat pematang/dinding kolam. Kemiringan tanah yang baik untuk pembuatan kolam berkisar antara 3-5\% untuk memudahkan pengairan kolam secara gravitasi. Ikan nila cocok dipelihara di dataran rendah sampai agak tinggi $(500 \mathrm{~m} \mathrm{dpl})$. Untuk membuat kolam pembibitan perlu diperhatikan beberapa parameter air kolam pembibitan antara lain suhu, ketinggian, nilai $\mathrm{pH}$, amonia, oksigen terlarut, dan tingkat kekeruhan air.

Suhu atau temperatur air sangat berpengaruh terhadap metabolisme dan pertumbuhan organisme serta memengaruhi jumlah pakan yang dikonsumsi organisme perairan.Suhu juga memengaruhi oksigen terlarut dalam perairan. Suhu optimal untuk hidup ikan nila pada kisaran 14-38 ${ }^{\circ} \mathrm{C}$.Secara alami ikan ini dapat memijah pada suhu $22-37^{\circ} \mathrm{C}$ namun suhu yang baik untuk perkembangbiakannya berkisar antara $25-30{ }^{\circ} \mathrm{C}$.

Untuk ikan yang baru ditebar dengan ukuran antara 8-10 $\mathrm{cm}$ atau berat sekitar 5-10 g, ketinggian awal air kolam cukup sekitar 60-75 cm. Ketinggian air tersebut kemudian ditambah sesuai dengan perkembangan ikan. Dua minggu pertama, ketinggian air ditambah $10 \mathrm{~cm}$. Pada minggu keempat, ketinggian air ditambah lagi $10 \mathrm{~cm}$. Ketinggian air terus ditambah setiap dua minggu sebanyak $10 \mathrm{~cm}$. Pada akhir pemeliharaan, tinggi air menjadi 100-150 cm. [3]

Nilai pH merupakan indikator tingkat keasaman air yang antara lain dipengaruhi oleh aktivitas fotosintesis, suhu, dan terdapatnya anion dan kation dalam air. Nilai $\mathrm{pH}$ yang ditoleransi ikan nila berkisar antara 5 hingga 11, tetapi pertumbuhan dan perkembangannya yang optimal adalah pada kisaran $\mathrm{pH} 7-8$.[4]

Kekeruhan air yang disebabkan oleh pelumpuran di dasar kolam juga akan memperlambat pertumbuhan ikan. Lain halnya bila kekeruhan air disebabkan oleh adanya plankton; air yang kaya plankton dapat berwarna hijau kekuningan dan hijau kecoklatan karena banyak 
mengandung diatom. Plankton ini baik sebagai makanan ikan nila, sedangkan plankton biru kurang baik.Tingkat kecerahan air karena plankton harus dikendalikan.[4]

\section{Mikrokontroller}

Arduino UNO R3 adalah sebuah board mikrokontroler yang didasarkan pada ATmega328 (datasheet). Arduino UNO R3 mempunyai 14 pin digital input/output (6 di antaranya dapat digunakan sebagai output PWM), 6 input analog, sebuah osilator kristal $16 \mathrm{MHz}$, sebuah koneksi USB, sebuah power jack, sebuah ICSP header, dan sebuat tombol reset. Arduino UNO R3 memuat semua yang dibutuhkan untuk menunjang mikrokontroler, mudah menghubungkannya ke sebuah computer dengan sebuah kabel USB atau mensuplainya dengan sebuah adaptor AC ke DC atau menggunakan baterai untuk memulainya. [5]

\section{Perangkat Keras dan Lunak}

\section{Sensor Photodioda}

Photo dioda adalah sensor cahaya yang termasuk kategori sensor cahaya photo conductive yaitu sensor cahaya yang akan mengubah perubahan intensitas cahaya yang diterima menjadi perubahan konduktansi pada terminal sensor tersebut. Dioda photo merupakan sensor cahaya yang akan mengalirkan arus listrik satu arah saja dimana akan menglirkan arus listrik dari kaki anoda ke kaki katoda pada saat menerima intensitas cahaya. [6]
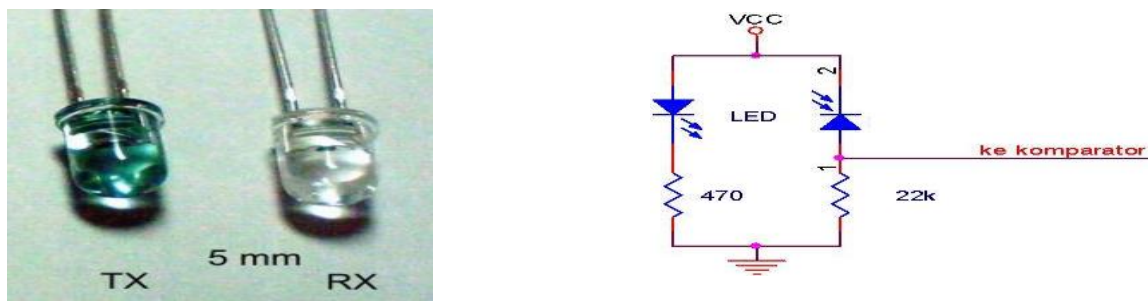

Gambar 1.Bentuk Fisik dan rangkaian Photo Dioda

\section{Sensor Suhu DS18B20}

Suhu adalah besaran yang menyatakan derajat panas dingin suatu benda atau lingkungan. Sensor suhu adalah komponen elektronika yang memiliki fungsi untuk mengubah besaran suhu menjadi besaran listrik dalam bentuk tegangan. [7]



Gambar 2.Sensor DS18B20 
Sensor suhu DS18B20 suhu beroperasi dalam kisaran $-55^{\circ} \mathrm{C}$ sampai $125^{\circ} \mathrm{C}$, dan memiliki tingkat keakuratan $\pm 0,5^{\circ} \mathrm{C}$ dalam kisaran $-10^{\circ} \mathrm{C}$ sampai $85^{\circ} \mathrm{C}$. Sensor DS18B20 memiliki keakuratan tinggi dan kemudahan perancangan jika dibandingkan dengan sensor suhu yang lain, juga mempunyai keluaran impedansi yang rendah dan linieritas yang tinggi sehingga dapat dengan mudah dihubungkan dengan rangkaian kendali khusus serta tidak memerlukan penyetelan lanjutan.

\section{Light Dependent Resistor (LDR)}

LDR adalah resistor yang nilai resistansinya berubah-ubah karena adanya intensitas cahaya yang diserap. LDR juga merupakan resistor yang mempunyai koefisientemperature negative, dimana resistansinya dipengaruhi oleh intrensitas cahaya.

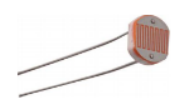

Gambar 3. Sensor LDR

\section{Modem Wavecom}

Modem berasal dari singkatan MOdulator DEModulator. artinya modem adalah alat komunikasi dua arah. Modem Wavecom adalah produk dari pabrik asal Perancis yng terletak di kota Issy-les-Moulineaux yaitu Wavecom.SA yang berdiri sejak 1993. Modem Wavecom ini cukup dikenal di Indonesia pada industri rumahan sampai sekala besar, mulai dari fungsi untuk SMS (Short Message Service) massal hingga penggerak perangkat elektronik, didukung pula dengan modem wavecom yang berjalan dengan baik di Quik Gateway pada software Quick SMS.

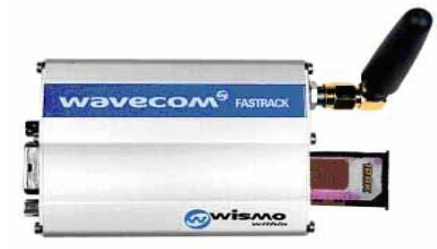

Gambar 4. Bentuk fisik GSM Modem

Keuntungan menggunakan Modem Wavecom Fastrack daripada Modem GSM atau HP:

a. Wavecom jauh lebih stabil dibanding Modem GSM.

b. Wavecom tidak gampang panas dibanding Modem GSM.

c. Pengiriman SMS yang lebih cepat dibanding Modem GSM atau HP (1000 s/d 1200 SMS per jam) Support AT Command, bisa cek sisa pulsa, cek point, cek pemakaian terakhir dll

\section{Relay}

Relay adalah komponen elektronika berupa saklar elektronik yang digerakkan oleh arus listrik. Secara prinsip, relay merupakan tuas saklar dengan lilitan kawat pada batang besi (solenoid) di dekatnya. Ketika solenoid dialiri arus listrik, tuas akan tertarik karena adanya gaya magnet yang terjadi pada solenoid sehingga kontak saklar akan menutup. Pada saat arus dihentikan, gaya magnet akan hilang, tuas akan kembali ke posisi semula dan kontak saklar kembali terbuka. [8] 


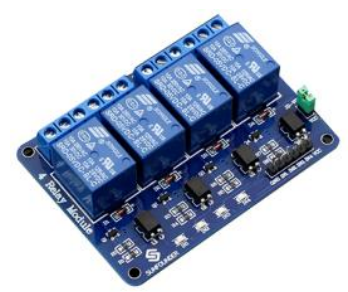

Gambar 5. Bentuk Fisik Relay

Konfigurasi dari kontak-kontak relay ada tiga jenis, yaitu:

a. Normally Open (NO), apabila kontak-kontak tertutup saat relay dicatu

b. Normally Closed (NC), apabila kontak-kontak terbuka saat relay dicatu

c. Change Over $(\mathrm{CO})$, relay mempunyai kontak tengah yang normal tertutup, tetapi ketika relay dicatu kontak tengah tersebut akan membuat hubungan dengan kontak-kontak yang lain.

\section{Buzzer}

Buzzer adalah sebuah komponen elektronika yang berfungsi untuk mengubah getaran listrik menjadi getaran suara. Pada dasarnya prinsip kerja buzzer hampir sama dengan loudspeaker, jadi buzzer juga terdiri dari kumparan yang terpasang pada diafragma dan kemudian kumparan tersebut dialiri arus sehingga menjadi elektromagnet, kumparan tadi akan tertarik ke dalam atau keluar, tergantung dari arah arus dan polaritas magnetnya, karena kumparan dipasang pada diafragma maka setiap gerakan kumparan akan menggerakkan diafragma secara bolak-balik sehingga membuat udara bergetar yang akan menghasilkan suara. Buzzer biasa digunakan sebagai indikator bahwa proses telah selesai atau terjadi suatu kesalahan pada sebuah alat (alarm).

\section{Pompa}

Pompa adalah suatu alat pengangkut untuk memindahkan zat cair dari suatu tempat ke tempat lain dengan memberikan gaya tekan terhadap zat yang akan dipindahkan,seperti misalnya pemindahan crude oil dari tanki penambungan bahan baku yang akan dialirkan ke kolom Destilasi. Pada dasarnya gaya tekan yang diberikan untuk mengatasi friksi yang timbul karena mengalirnya cairan di dalam pipa saluran karena beda evevasi (ketinggian) dan adanya tekanan yang harus dilawan.

\section{Heater}

Desain rangkaian driver keluaran valve, dan heater adalah sama, yaitu menggunakan driver relay yang bila dipicu tegangan $5 \mathrm{~V}$ akan terhubung ke tegangan $220 \mathrm{~V}$ yang akan dihubungkan ke keluaran.

\section{METODE PENELITIAN}

Blok diagram dari penelitian ini ditunjukkan pada Gambar 6.

Keterangan Blok Diagram:

a. Power supply berfungsi memberikan supply tegangan kesemua rangkaian yang ada.

b. Mikrokontroler adalah pengontrol utama sistem keamanan secara keseluruhan.

c. Relay berfungsi mengaktifkan pompa heater dan buzzer. 
d. Modem berfungsi sebagai interface pengirim data SMS, dalam hal ini modem yang digunakan adalah modem wavecom fastrack.

e. Sensor yang digunakan adalah Sensor photodiode, sensor suhu,sensor LDR .

f. Heater berfungsi untuk meningkatkan suhu

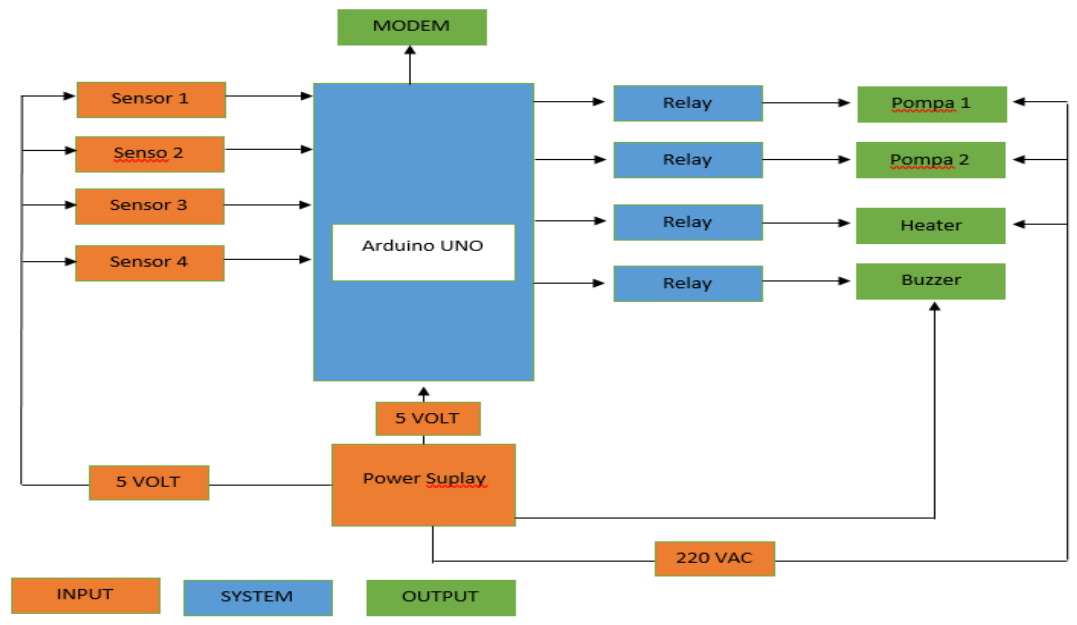

Gambar 6. Blok Diagram Penelitian

\section{HASIL DAN PEMBAHASAN}

\section{Pengukuran}

Pengukuran Tegangan Output Mikrokontroler

Besar tegangan yang digunakan yaitu 5 Volt DC yang berasal dari catu daya dan ini digunakan sebagai sumber tegangan pada Arduino Uno dan penggerak relay. Pengukuran dilakukan pada mikrokontroler di mana pin 5V untuk Vec dan pin GND untuk GND.

Tabel 1. Penentuan Ketinggian Sensor Level Air

\begin{tabular}{lll}
\hline Sensor & Ketinggian Level $(\mathrm{cm})$ & Kondisi Level Air \\
\hline 1 & $7 \mathrm{~cm}$ & Kurang Air \\
\hline 2 & $14 \mathrm{~cm}$ & Normal \\
\hline 3 & $21 \mathrm{~cm}$ & Air Lebih \\
\hline
\end{tabular}

\section{Pengukuran Tegangan Sensor Level Ketinggian}

Tabel 2. Logika sensor level Ketinggian Air

\begin{tabular}{ccc}
\hline Sensor Batas Tinggi & Sensor Batas Normal & Sensor Batas Bawah \\
\hline 0 & 0 & 0 \\
\hline 0 & 0 & 1 \\
\hline 0 & 1 & 0 \\
\hline 1 & 0 & 0
\end{tabular}

Pengukuran Output sensor Photodioda 
Dari hasil pengukuran pada Tabel 3 dapat diketahui bahwa tegangan output sensor di bawah 1 Volt dalam keadaan LOW yang menunjukan pelampung menutup cahaya masuk ke sensor photodioda. Kondisi LOW ini yang mebuat relay membaca sebagai logika 1 dan mengaktifkan Normaly Close. Pada saat tegangan lebih dari 1 volt sensor membaca keadaan HIGH yang menunjukan sensor tidak terhalang pelampung.

Tabel 3. Pengukuran Tegangan Output Sensor Photodioda

\begin{tabular}{ccccccc}
\hline $\begin{array}{c}\text { Sensor } \\
\text { Atas } \\
(\mathrm{V})\end{array}$ & $\begin{array}{c}\text { Sensor } \\
\text { Normal } \\
(\mathrm{V})\end{array}$ & $\begin{array}{c}\text { Sensor } \\
\text { Bawah } \\
(\mathrm{V})\end{array}$ & $\begin{array}{c}\text { Kondisi } \\
\text { Air }\end{array}$ & \multicolumn{2}{c}{ POMPA } & Keterangan \\
\cline { 1 - 1 } & 0.1 & 0.1 & - & Kuras & Isi & Mengirim SMS alat Aktif \\
\hline 4.1 & 4.2 & 0.2 & $\begin{array}{c}\text { Level air } \\
\text { rendah }\end{array}$ & OFF & ON & $\begin{array}{c}\text { Mengirim SMS level ketinggian } \\
\text { air rendah dan pemberitahuan } \\
\text { pompa pengisan aktif }\end{array}$ \\
\hline 4.3 & 0.1 & 4.1 & $\begin{array}{c}\text { Level air } \\
\text { tinggi }\end{array}$ & OFF & OFF & $\begin{array}{c}\text { Mengirim SMS Lever } \\
\text { ketinggian air dan } \\
\text { pemberitahuan Semua Pompa } \\
\text { mati }\end{array}$ \\
\hline 0.1 & 4.2 & 4.1 & $\begin{array}{c}\text { Level air } \\
\text { tinggi }\end{array}$ & ON & OFF & $\begin{array}{c}\text { Mengirim SMS level ketinggian } \\
\text { air tinggi dan pemberitahuan } \\
\text { Pompa Pembuangan aktif }\end{array}$ \\
\hline
\end{tabular}

\section{Pengukuran Sensor Suhu}

Tabel 4. Hasil Pengukuran Sensor DS18B20

\begin{tabular}{ccccc}
\hline No & Termometer $\left({ }^{\circ} \mathrm{C}\right)$ & Sensor Suhu $\left({ }^{\circ} \mathrm{C}\right)$ & Selisih Pembacaan $\left({ }^{\circ} \mathrm{C}\right)$ & Heater \\
\hline 1 & 7.0 & 7.31 & 0.31 & ON \\
\hline 2 & 15.0 & 15.27 & 0.27 & ON \\
\hline 3 & 20.1 & 20.48 & 0.38 & ON \\
\hline 4 & 23.0 & 23.34 & 0.34 & ON \\
\hline 5 & 25.1 & 25.47 & 0.37 & OFF \\
\hline 6 & 27.1 & 27.25 & 0.15 & OFF \\
\hline 7 & 30.0 & 30.35 & 0.35 & OFF \\
\hline 8 & 32.0 & 32.21 & 0.21 & OFF \\
\hline 9 & 35.0 & 35.46 & 0.46 & OFF \\
\hline 10 & 38.1 & 38.44 & 0.34 & OFF \\
\hline
\end{tabular}

Berdasarkan hasil pengukuran pada Tabel 4 selisih antara suhu pembacaan termometer digital dengan suhu dari sensor sangat kecil yaitu $0,32^{\circ} \mathrm{C}$. Ini di karenakan sensor DS18B20 memiliki kehandalan yang baik, namun tidak dipungkiri bahwa adanya perbedaan yang terjadi. Pada saat suhu berada di bawah $25^{\circ}$ maka secara otomatis alat akan mengaktifkan heater. 


\section{Pengukuran Tegangan Sensor Kejernihan}

Tabel 5 . Pengukuran Sensor Kejernihan

\begin{tabular}{|c|c|c|c|}
\hline Waktu & Konsentrasi & Vout LDR (Volt) & Keterangan \\
\hline \multirow{10}{*}{ Siang } & Tanpa Air & 3.4 volt & Bersih \\
\hline & Air & 3.4 volt & Bersih \\
\hline & Warna Hijau $15 \mathrm{ml}$ & 1.6 volt & Kotor \\
\hline & Warna Hijau 30 ml & 1.2 volt & Kotor \\
\hline & Warna Hijau 45 ml & 0.8 volt & Kotor \\
\hline & Warna Coklat $15 \mathrm{ml}$ & 0.9 volt & Kotor \\
\hline & Warna Coklat $30 \mathrm{ml}$ & 0.6 volt & Kotor \\
\hline & Warna Coklat 45 & 0.4 volt & Kotor \\
\hline & Pelet 25 gram & 1.8 volt & Kotor \\
\hline & Pelet 50 gram & 1.2 volt & Kotor \\
\hline \multirow{10}{*}{ Malam } & Tanpa Air & 3.2 volt & Bersih \\
\hline & Air & 3.1 volt & Bersih \\
\hline & Warna Hijau $15 \mathrm{ml}$ & 1.5 volt & Kotor \\
\hline & Warna Hijau $30 \mathrm{ml}$ & 1 volt & Kotor \\
\hline & Warna Hijau 45 ml & 0.6 volt & Kotor \\
\hline & Warna Coklat $15 \mathrm{ml}$ & 0.8 volt & Kotor \\
\hline & Warna Coklat $30 \mathrm{ml}$ & 0.5 volt & Kotor \\
\hline & Warna Coklat $45 \mathrm{ml}$ & 0.2 volt & Kotor \\
\hline & Pelet 25 gram & 1.2 volt & Kotor \\
\hline & Pelet 50 gram & 0.6 volt & Kotor \\
\hline
\end{tabular}

Pada Tabel 5 diatas dapat diketahui bahwa sensor LDR dipengaruhi oleh jumlah cahaya yang diterima permukaan sensor. Pada warna hijau tegangan output sensor pada saat siang hari mengalami penurunan tegangan sebesar 0.4 volt pada saat malam hari terjadi penurunan tegangan rata-rata 0.45 . Pada warna coklat siang hari terdapat perbedaan sebesar rata-rata 0.25 volt setiap panambahan $15 \mathrm{ml}$ pewarna, dimana kondisi kekeruhan pada malam hari 0.3 volt. Pengujian menggunakan pelet 25 dan 50 gram pada siang hari mengalami penurunan tegangan 0.6 volt dan 0.6 volt pada malam hari.

\section{Pengujian Modem Wavecome Fastrack}

Pengujian modem ini berguna untuk mengetahui modem dapat mengirm SMS ke pengguna dengan baik. Menghubungkan Tx dan RX modem GSM dengan port pada Arduino menggunakan kabel jumper yang sudah disediakan dan menganalis waktu pengiriman SMS dari modem ke ponsel.

\section{Pengujian Perangkat Keras ( Hardware) Pengujian BOARD ARDUINO UNO}

Mengunduh program ke board arduino,yang akan mengaktifkan LED yang akan meyalakan LED selama satu detik dan kemudian padam selama satu detik demikian seterusnya. Maka rangkaian board arduino dalam keadaan baik.

\section{Pengujian Sensor Suhu.}

Pengujian pada sensor suhu DS18B20 ini dilakukan untuk mengetahui kemampuan pembacaan atau ke akuratan terhadap perubahan suhu dan apakah alat dapat bekerja secara otomatis mengaktifkan heater .Membadingkan hasil pengukuran sensor dengan termometer sehingga akan terlihat ke akuratan dari sensor. Pengujian ini dilakukan dengan cara mengkondisikan suhu air pada akuarium dan mengambil beberapa hasil pengukuran. 


\section{Pengujian Sensor kejernihan}

Pengujian pada sensor ini bertujuan untuk mengetahui sensor mendeteksi kondisi pada saat air jernih dan ketika air keruh. Pengujian ini dilakukan dengan cara menggunakan lampu sebagai penghasil cahaya dan sensor LDR sebagai penangkap cahaya . Pada saat air jernih intesitas cahaya yang diterima sensor tinggi sehingga meningkatkan tegangan pada output LDR dan saat air kotor intesitas cahaya yang diterima oleh LDR rendah sehingga mempengaruhi tegangan output dari sensor tersebut. Adapun penggujian ini dilakukan dengan cara memasukkan pewarna makanan berwarna hijau, coklat dan menggunakan pelet yang mesimulasikan air berlumut atau kotor. Fungsi sensor kekeruhan diuji siang dan malam hari untuk mengetahui apakah ada perbedaan nilai yang diterima sensor pada kondisi malam dan siang hari.

\section{Pengujian Sensor Ketinggian Air}

Pengujian pada sensor ketinggian dilakukan dengan cara melihat kemampuan sensor photodioda mendeteksi cahaya . Ketika Cahaya dari infrared tertutup maka photodioda mengirim sms kondisi .

\section{Pengujian Modem}

Tabel 6. Pengujian Modem

\begin{tabular}{llll}
\hline Sensor & Keterangan & Status Sms & $\begin{array}{l}\text { Durasi } \\
\text { Penerimaan }\end{array}$ \\
\hline LDR & Kotor & Terkirim & 19.29 \\
\hline LDR & Jernih & Terkirim & 14.04 \\
\hline Suhu & 7.31 & Terkirim & 14.13 \\
\hline Suhu & 15.27 & Terkirim & 14.12 \\
\hline Suhu & 23.34 & Terkirim & 15.23 \\
\hline Suhu & 25.47 & Terkirim & 20.11 \\
\hline Suhu & 30.35 & Terkirim & 13.56 \\
\hline Suhu & 38.44 & Terkirim & 14.11 \\
\hline Suhu & 40.311 & Terkirim & 14.22 \\
\hline Level Tinggi & 1.0 .0 & Terkirim & 13.51 \\
\hline Level Normal & 0.1 .0 & Terkirim & 11.59 \\
\hline Level Bawah & 0.0 .1 & Terkirim & 12.13 \\
\hline
\end{tabular}

Dari Tabel 6 di atas dapat dilihat bahwa pengujian modem dari sensor suhu, LDR, dan Level keberhasilan pengirman $100 \%$ tetapi adanya perbedaan waktu yang terjadi saat pengiriman hal ini disebabkan oleh kondisi sinyal pada modem atau pada ponsel kuat atau tidak, trafik lalulintas pada provider yang digunakan, dan kecepatan mikrokontroler saat mengolah data. 


\section{Pengujian Pompa (Output Hardware)}

Tabel 7. Pengujian Pompa

\begin{tabular}{llll}
\hline \multirow{2}{*}{ No } & Output Hardware & Kondisi air & Waktu \\
\hline \multirow{2}{*}{1} & \multirow{2}{*}{ Pompa pengisian } & Kosong - Normal & 45 detik \\
\cline { 3 - 4 } & & Rendah - Normal & 35 detik \\
\hline \multirow{2}{*}{2} & \multirow{2}{*}{ Pompa Pengurasan } & Tinggi - Normal & 33 detik \\
\cline { 3 - 4 } & Normal - Rendah & 38 detik \\
\hline 3 & Heater & Dingin - Normal & 6,41 menit \\
\hline
\end{tabular}

Adanya perbedaan waktu pengisian antara rendah ke normal dan normal ke rendah di sebabkan pompa air yang digunakan berbeda merek sehingga dapat terjadinya perbedaan akan kualiatas alat.

Pengujian sistem secara keseluruhan.

Tabel 8. Pengujian Keseluruhan

\begin{tabular}{|c|c|c|c|c|}
\hline \multirow{2}{*}{ Kondisi Air } & \multirow{2}{*}{ Heater } & Pompa & \multirow{2}{*}{ Buzzer } & \multirow{2}{*}{ Modem } \\
\hline & & Kuras & & \\
\hline Air Dingin & & - & - & \\
\hline Air Sedang & - & - & - & \\
\hline Kotor & - & & - & \\
\hline Bersih & - & - & - & \\
\hline Level Air Lebih & - & & - & \\
\hline Level Air Normal & - & - & - & \\
\hline Level Air Rendah & - & - & & \\
\hline
\end{tabular}

Pengujian terakhir yang dilakukan adalah pengujian Prototipe menyeluruh dalam ruangan simulasi yang telah dibuat, untuk mengetahui apakah alat yang dibuat bekerja sesuai dengan yang direncanakan. Pengujian ini menggunakan air sebagai variabel yang diukur, serta pengujian dilakukan secara bergantian dimulai dengan pengujian ketinggian air kemudian kekeruhan air dan terakhir suhu air untuk mengetahui apakah prototipe sistem telah berjalan dengan baik.

Tabel 8 memperlihatkan simulasi kerja sistem secara keseluruhan. Ketika alat di-ON-kan kondisi wadah dalam keadaan kosong, pompa dalam keadaan mati dan alarm off. Pada saat alat dalam keadaan siap untuk dioperasikan alat akan mengirim sms pada handphone bahwa "alat telah aktif". Kemudian alat akan beroperasi secara otomatis untuk percobaan pertama yang dilakukan adalah alat mengecek kondisi level air. Pada saat air dalam kondsi kosong atau rendah alat akan mengirim sms pemberitahuan bahwa "air rendah dan mengaktifkan pompa untuk pengisian air". Setelah mencapai kondisi level normal maka alat mengirim sms informasi "air normal pompa pengisian off". Pada saat kondisi air sangat banyak atau tinggi maka alat akan mengirim sms "kondisi air tinggi, aktifkan pompa pembuangan ", setelah normal mengirim sms bahwa kondisi " air normal semua pompa mati ".

Pada percobaan kedua yang dilakukan ialah alat mengecek kejernihan air dengan cara memasukkan zat pewarna makanan pada saat kondisi air jernih maka alat memberikan informasi bahwa "air jernih ". Pada kondisi air kotor atau intensitas Cahaya yang mengenai permukaan LDR kurang dari 70\% maka alat mengirim sms " air Kotor, aktifkan pompa pembuangan " kemudian pompa akan aktif sampai sensor level berada pada batas bawah kemudian alat akan 
mengisi air yang baru sampai batas normal kemudian mengirim sms " air normal, air jernih dan pompa pengisian mati“.

Percobaan ketiga yang dilakukan ialah alat mengukur suhu kondisi air sengan mengirim sms tentang suhu kondisi .pada saat kondisi suhu dibawah ukuran suhu normal yang ditetapkan $25^{\circ} \mathrm{C}-30^{\circ} \mathrm{C}$ maka alat akan mengirim sms kondisi suhu "air dingin aktifkan heater" kemudian heater akan mati saat mencapai $30{ }^{\circ} \mathrm{C}$ dan mengirim sms kondisi "suhu air normal heater di matikan"

Hasil percobaan dapat berjalan dengan baik menandakan bahwa program yang diinput ke dalam arduino dapat bekerja sesuai dengan yang diharapkan, dengan catatan bahwa kecepatan dan kualitas pengirim dan penerima pesan tergantung pada layanan serving profider atau kualitas sinyal.

\section{KESIMPULAN}

Penelitian ini memberikan kesimpulan bahwa pengukuran sensor LDR dipengaruhi jumlah cahaya yang diterima permukaan sensor. Pada saat siang hari tegangan output pada sensor lebih besar sekitar 0.1 volt dari pada saat malam hari, Hal ini disebkan oleh adanya perbedaan intesitas cahaya matahari dan lampu. Untuk pengukuran sensor photodioda dapat diketahui bahwa tegangan output sensor dibawah 1 Volt dalam keadaan LOW yang menunjukan pelampung menutup cahaya masuk ke sensor photodioda. Pada saat tegangan lebih dari 1 volt sensor membaca keadaan HIGH yang menunjukan sensor tidak terhalang. Sehingga dari hasil pengujian prototipe perangkat secara keseluruhan dapat disimpulkan bahwa alat mampu mensimulasikan kondisi air sehingga kebutuhan kolam pembibitan ikan terhadap ketinggian air, suhu dan kejernihan dapat dipenuhi.

\section{DAFTAR PUSTAKA}

[1] DIO RHEZA RIVANDI, "Pemeliharaan Induk Dan Larva Ikan Nila,” 2014.

[2] Anonim, "Panduan lengkap budidaya ikan nila." http://alamtani.com/budidaya-ikannila.html .

[3] Anonim, "Mengatur Ketinggian Air Kolam Nila," 2016.

[4] Pakan Alternatif Ternak, "No Title." https://pakanalternatiflele.wordpress.com/author/pakanalternatiflele/.

[5] R. . Aldaka, "Sistem Otomatisasi Pengkondisian Suhu, pH,dan Kejernihan Air Kolam Pada Pembudidayaan Ikan Patin," 2015.

[6] PPPPTK BOE Malang, Modul pengembangan keprofesian berkelanjutan (PKB) berbasis kompetensi. 2018.

[7] M. B. Ridwan, "Sistem Monitoring Tanaman Hidroponik Dengan Sensor PH, Suhu Air Dan Pemupukan Berbasis Internet of Thing," J. TeknoSains FTIE UTY, 2019.

[8] R. Yuliawiata, "Prototipe Sistem Ketinggian Dan Debit Air Pada Sungai Berbasis Mikrokontroler16," Tek. Inform. Univ. Islam Negri Sunan Kalijaga., 2013. 